\title{
Children's Criminal Jurisdiction System Against Narcotic Crimes in Children
}

\author{
Yuliana Yuli W, Davilla Prawidya Azaria, Aurora Jillena Meliala, Dwi Aryanti \\ Ramadhani, Sulastri
}

Faculty of Law, Veterans National Development University, Jakarta

Jl. RS. Fatmawati, Pondok Labu, South Jakarta 12450

Email: yuli080706@gmail.com,Phone No.:081285236878

\begin{abstract}
Imposing punishment for children is considered unwise, but it must be done because it is still essential to punish children, especially in cases of narcotics crime, so that the child's wrong attitude does not continue to become permanent until he is an adult and results in community unrest. The abuse of narcotics by children is a behavior violation and an act against the law. Penalties for narcotics offenders differ between adults and children. This is because it is to protect the rights of a child who is involved in a criminal act, especially in narcotics crime. This study aimed to determine the provisions of case handling for children who commit narcotics crimes and how to implement criminal sanctions against children who are offenders of narcotics crimes. The research method used is juridical normative with the results of the analysis that the provisions for handling cases for children who commit narcotics crimes can be seen in Law No. 11 of 2012 concerning the Juvenile Criminal Justice System, against children who are perpetrators of narcotics crimes by applying the diversion of children's cases, it can be resolved non-judicial that the involvement of children in the judicial process will give birth to stigmatization and affect the mental condition of the child. Criminal sanctions for narcotics offenders committed by children are based on specific considerations such as from a juridical perspective, sociological, psychological, and philosophical. The threat of punishment for children can only be imposed $1 / 2$ (one-half) of the greatest danger from an adult based on the provisions of the law due to diversion provision. It is hoped that judiciary involving children can be resolved non-judicial to reduce stigmatization and mental condition of children.
\end{abstract}

Keywords: Narcotics, Crime, Children

\section{INTRODUCTION}

\section{A. Background}

Children are candidates for the next generation who will replace the older generation in continuing the country's life-those who determine the nation's welfare in the future. Therefore, children and young people need to be well nurtured so that they do not take the wrong path in the association to prepare for their future lives.

In everyday association, relationships occur with one another, resulting in events or incidents that can drive legal regulations. One form of this incident among children is the abuse of narcotics. This is supported by progress in information technology, which is increasing rapidly, so this will directly or indirectly affect the development of the level of narcotics circulation among children.

The abuse of narcotics by children is a behavior violation or an act that violates the law. As for the factors that influence narcotics committed by children are usually influenced by elements from within and from outside the child such as relationships, education, playmates, and also the influence of their changing emotional life, more profound curiosity about something new sometimes leads them into negative things, especially when the child joins the circle of people who are already drug addicts.

Thus, it is hoped that the formulation of this law can tackle the illicit trafficking and abuse of narcotics and become a reference and guideline for courts and administrators or executors of court decisions that apply rules, especially judges in imposing criminal sanctions on crimes have occurred.

Law enforcement against the corruption of narcotics abuse itself has been carried out lot by law enforcement officials, this law enforcement is expected to be an antidote factor against the spread of illicit trafficking and narcotics trafficking, but the more intensive law enforcement is carried out, the circulation and trafficking in society also increase.

In the prevention of crime, two means are needed: law enforcement without using criminal or non-penal sanctions and using penalties or criminal sanctions. But talking about criminal sanctions for 
children often raises juridical, sociological, and philosophical issues. There is a paradigmatic dilemma related to the approach taken against children who commit narcotics abuse. Juridically, children who commit narcotics abuse are qualified as criminal offenders. But conceptually, because narcotics abuse qualifies as a crime whiteout victim, which means that the victim of the crime is the perpetrator himself, then in the case of narcotics abuse, the victim (offense) is the perpetrator.

Thus, conceptually children who commit narcotics abuse, in addition to their qualifications as perpetrators, are also victims. Then the problem of whether crimes committed by children with a background of delinquency and the development of an unstable mental attitude must be treated the same as adults. In this study, the case of narcotics abuse class I in the form of methamphetamine was carried out by children at the Samarinda District Court with the defendant Indahdita Yulianti Binti Arbain. Still, the public prosecutor appealed the judge's decision at the Samarinda District Court and the Samarinda High Court level until the end. The case must receive a cassation decision.

The state of Indonesia has legally protected children through a range of legislation and regulations, including Junior Court Law No. 11 of 2012 and Child Protection Law No. 23 of 2002. It is often found, however, that the treatment of children who commit criminal acts does not include legal security, strong encouragement and assurances of the enforcement of the rights of the child in the implementing of the justice systems in Indonesia. The problems that exist include the detention of children, the lengthy judicial process starting from investigations, prosecutions, courts that eventually place the child convict in a correctional facility which leaves trauma and negative implications for the child.

This is because the nature and psychological conditions of the child need special care and protection, especially against measures which can in essence damage the development of the child's mind and body. This is realized by starting with special treatment at the time of detention, namely holding children apart from adults. The examination is carried out in a separate section separate from the adult section.

The police investigating apparatus is often seen as the central pillar of criminal law enforcement in general and juvenile criminal law. The police conduct investigations and investigations to gather sufficient evidence to proceed to the next stage of justice.
In carrying out their duties as the main gate of the criminal justice process, police investigators bear a heavy burden. Police investigators must be outstanding investigators and also have good judgment. Police investigators must carry out filters against the flow of cases that come in. Not all criminal cases entered and accepted by police investigators are forwarded to the next stage of justice. Police investigators are given discretionary policy powers to continue or not criminal proceedings to the next step. Then there must be sufficient preliminary evidence to make an arrest.

As a series of investigative processes, the investigation intends to find a bright spot on who the perpetrator or suspect is. Article 1 point 2 states that "an investigation is a series of actions by an investigator in terms and according to the manner stipulated in the Criminal Procedure Code (KUHAP) to seek and collect evidence which with that evidence sheds light on the criminal act that has occurred in order to find the suspect." -the things described above, and driven by the increasing prevalence of narcotics abuse among children, this research is for the author interested in conducting research entitled "The Criminal Justice System of Children Against Narcotics Crimes in Children".

\section{B. PROBLEM FORMULATION}

Based on the background described above, the problems in this study include:

1. What are the provisions for handling cases for children who commit narcotics crimes?

2. How is the application of criminal sanctions against children of narcotics offenders?

\section{RESEARCH METHODS}

Juridical research is a scientific activity based on methods, methods, systems and specific ideas which seeks by analyzing one or more phenomena of specific laws. In addition, the legal details are often thoroughly examined in order to find solutions to the issues in this phenomenon. The author therefore uses the science method to collect materials or data sources necessary for the achievement of the objects for research in the writing of this review.

\section{DISCUSSION}

\section{A. Case Handling for children who commit the Narcotics Crime}

In Indonesia the minimum age for criminal liability for children was young, i.e. 8 years. Via a 
decision of the Constitutional Court, this restriction of low age was then reversed by specifying that the criminal liability limit for children is 12 years. The decision was subsequently implemented in Article 1, No 3 of the Criminal Justice System for children, Law No 11 of 2012, which specifies that children of 12 years of age, but under the age of 18 years of age suspect of committing a criminal offense. Article 20 of this Law also states, if the child undertaking an illegal act is not yet 18 years of age but has exceeded the age of 18 but has not yet attained 21 years, that the child undertaking the illegal act is still entitled to immunity under the provisions of the SPPA Law.

(ii) resolving children out of court, and (iii) sparing a child from freedom deprivation; (iv) fostering group participation, and (v) promoting a sense of duty in the child. Diversion is aiming for I achieving reconciliation among the victim and the child. Diversion shall take place at any level of investigation except for exams at appeal level and cassation level, in Law No. 11 of 2012 on the Criminal Justice System for Children. Undermine can only be perpetrated against a child if the child commits an offense that cannot be re-presented and that is punishable by imprisonment for less than 7 years.

The procedure for the discharge of children can also be carried out within the framework of drug crime as regulated in Law No. 39 of 2009 on drug products, which is also part of a nonvictimized crime, by referring to circular no. 4/2010 concerning the placement of violence and abuse by the Supreme Court. And Supreme Court Circular (SEMA) number 3 of 2011 for placement of the victims of drug abuse in medical rehabilitation and in social rehabilitation institutions. Narcotics addicts for medical rehabilitation or social rehabilitation. The proceedings also apply in putting both SEMAs in the context of diversion, because, generally speaking, drug offences are subject to imprisonment for over seven years other than the criminal actions provided for in Article 127 of Law No. 39 of 2009 concerning narcotical products. After all, the children involved in drug crime need to be optimized for safe medical and social care.

Under Article 6 letter a, diversions in relation to the Criminal Justice System for Children as laid down in Law No.11 of 2012 are based on a peace arrangement between the victim's family of the victims and the child's family of the child. The diversion agreement is thus essential to ensure that the diversion phase is effective. In order to reach a diversion agreement, investigators, public prosecutors, judges shall be responsible for the diversion process, by deliberations involving children and children and their parents, victims and parents and guardian workers, social advice providers and social workers taking account: And j. support for the community and the family.

In the examination at the appeal and cassation level, the obligation to make diversion is not explicitly stated. If you look at the examination process without the parties' physical presence, the hobby only stops at the examination stage at the District Court. The results of the diversion are stated in a peace agreement which must be forwarded to the Court so that a court order can be made, which can be in the form of:

a. peace with or without compensation;

b. return to the parent/guardian;

c. participation in education or training in educational institutions or LPKS no later than 3 (three) months; or

d. society service.

Law No.11 of 2012 concerning the Juvenile Criminal Justice System also provides an opportunity for diversion without the consent of the victim and the victim's family by involving a social advisor based on the following conditions:

a. a criminal act in the form of a violation;

b. minor criminal offense;

c. a crime without victim; or

d. the value of the victim's loss is not more than the value of the provincial minimum wage; and e. based on the recommendation of the Community Advisor

The diversion carried out also had to be led by Regulation No 2 of the 2012 Supreme Court on Adjustment of Minor Crime Limits, which established the loss limit Rp. $2.500 \quad 000.00$, especially for minor crimes with a loss value to the victim. Diversion can occur, as already discussed, at the stage of the judicial review. Diversion is specially governed by Regulation No 4 of the Supreme Court on the Guidelines for implementing Diversion in the System of Juvenile Criminal Justice during the review at the Court. Diversion may take place under the rule of the Supreme Court when a child commits an offense punishable by imprisonment for less than seven years or when the child is also charged with other charges of alternative charges, subsidiarity, cumulative or combined charges for imprisonment for more than seven years.

In essence, diversion in this Supreme Court Regulation emphasizes that if in one of the charges there is an act which is punishable by a sentence of fewer than seven years, then the child has the right to get the diversion process. The Supreme Court Regulation is compatible with the concept of 
diversion stipulated in the SPPA Law, which focuses on an agreement/agreement between the perpetrator and the victim. The only difference is that the diversion agreement must not conflict with the law, religion, local community decency, morals, or contain things that are impossible for the child to do or have bad intentions.

\section{B. Implementation of Criminal Sanctions against child perpetrators of the Narcotics Crime}

Children who are faced with the law have the term, namely children as victims of funds, children as perpetrators, and children as witnesses. Victims suffer physically and spiritually due to their actions or from other parties who want to seek fulfillment of their own or other's interests that are contrary to their human rights. Perpetrators of Criminal Actions According to R. Achmad Soema Di Prada is a person who commits, orders to do, participates in doing, and deliberately induces to commit the act.

As for the legal age limit for children's responsibility, according to Nandang Sambas: "Juridically, determining the age limit of a child will have legal consequences concerning issues of rights and obligations for the child himself. Thus, the formulation of children in various laws does not provide an understanding of the conception of a child, but rather a formulation which is a limitation for certain actions, certain interests, and certain purposes ". According to Djamali M. Nasir: "The age limit of a child gives a grouping for a person to be later referred to as a child. What is meant by the age limit is the grouping of the maximum age as a manifestation of the child's ability to have legal status, so that the child has the status of becoming an adult or a legal subject who can be independently responsible for the child's actions and legal actions ".

As the focus of prevention and eradication of substance addiction and illicit narcotics (P4GN), the National Narcotics Agency (BNN) has pocketted up 3.376.115 individuals aged 10-59 years as numerous users in 2017. Meanwhile, in 2018 (in 13 provincial capitals in Indonesia), the number of drug abuses among students was 2.29 million. The ages $15-35$ or the thousandth generation are a group of people vulnerable to substance abuse. Based on data from 2014 to 2019, children who used narcotics, psychotropics and additives (drugs) reached 394 children, which was reported to the Indonesian Child Protection Commission (KPAI). About 20 minors are drug users last year. Children who are drug dealers, psychotropics and additives (drugs) cross 153 children between 2014 and 2019. Moreover, from
2014 to 2019 data on children at odds with the law $(\mathrm{ABH})$ reached 88,831 children, including offenders, victims and witnesses.

Narcotic regulations in Indonesia, formerly Law No. 22 of 1997, are governed by Law No. 35 of 2009 on Narcotics. This is aimed at eliminating, preventing, protecting and avoiding drug violence. In the Republic of Indonesia Law No. 11 of 2012, which concerns the system of youth criminal justice, the punishment of children involved in drug abuse shall be governed by the (SPPA). The way in which criminals of the rule, adults as well as juveniles, handle the penalty differently. A child who is in conflict with the law is a child who is 12 before the age of 18 and who, pursuant to Article 1 of Law 11 of 2012, is accused of committing a criminal act relating to SPPA.

In accordance with Article 5 of the SPPA Act, priority must be given to the restructuring approach. Restructuring Justice involves settling criminal cases with defendants, victims, perpetrators' families and other related parties to work together for a just remedy through a re-establishment of the original condition, rather than retribution. Restaurant justice is applied to the exercise of distraction, which is possible when imprisonment is less than seven years and not a repeat of a criminal act. Diversion is a distraction from formal proceedings in the handling of children suspected of having committed a criminal offence. The divergence technique can be used to resolve children's allegations that contravene law. Since the narcotics legislation No. 35 of 2009 expressly does not refer to children's penalties.

According to the SPPA Law, a child criminal offender can be subject to two types of sanctions, namely Actions, for criminal offenders who are not yet 14 years old based on Article 69 paragraph (2) of the SPPA Law and Pidana, for criminal offenders who are not yet 15 years old.

1) Action sanctions that can be imposed on children under Article 82 of the SPPA Law include: - Returns to parents / guardians

- Submission to someone;

- Treatment in a mental hospital;

- Treatment at LPKS

- Obligation to attend formal education and training held by the government or private bodies;

- Revocation of driving license; and

- Correction due to criminal action

2) Criminal Sanctions that can be imposed on juvenile offenders are divided into the main and additional penalties based on Article 71 of the SPPA Law:

The Principal Crime consists of: 
- Criminal warning

- Criminal with the following conditions:

Development outside of institutions, community services, or supervision;

- Work training;

- Development in institutions;

- Jail.

Additional Criminal consists of:

- Deprivation of profits derived from criminal acts; or

- Fulfillment of customary obligations.

In the meantime, penalties are to be imposed on the parent and guardian of children aged 12 and subject to the law of SPPA and engage in schooling, coaching or guidance programs at the regional and central level of government or the LPKS. Six months. Six months. Minors can be punished by a maximum jail term of $1 / 2(1 / 2)$ for adults. Given the limited capacity to think, the parents or guardians are under their supervision.

The transfer of the child to a youth prison shall be appointed when a child reaches 18 years of age and fails to serve a sentence at the LPKA, based on Article 86 of the Law, and when he reaches the age of twenty-one and has not finished serving a penalty. To a correctional institution for adults.

In accordance with Article 90 of the SPPA Law the legislative provisions include the same protections as: the children of victims and the children of witnesses

a. Medical rehabilitation and social rehabilitation efforts, both inside and outside the institution

b. Safety assurance, both physical, mental, and social

c. Ease of obtaining information about case developments.

As much as possible, detention and punishment of children should be prevented or used as a last resort. Children who abuse narcotics, if placed in the formal criminal justice system, will undoubtedly suffer a harmful impact. This violates children's rights. Through diversion, children who abuse narcotics get protection. Recreation provides protection of children's human rights. According to the researcher's view, minors who become couriers or commit drug abuse are considered victims other than perpetrators. In connection with the problem of Narcotics, children become attractive targets by drug dealers to make money printing tools, in which children are still easily influenced or unstable. So that the solution through the approach taken can use restorative justice to achieve and carry out Diversion, this is because children are legal subjects who have committed a criminal act, so children are still the perpetrators who must be accountable for their actions to provide learning.
Still, children are also victims even though their efforts need to be accounted for.

\section{CLOSING}

\section{A. Conclusion}

From the discussion in the previous chapters, conclusions can be drawn, including:

1. Provisions for the handling of cases for children who commit narcotics crimes can be seen in Law No.11 of 2012 concerning the Juvenile Criminal Justice System, against children who are perpetrators of narcotics crimes by enforcing the diversion of children's cases can be resolved nonjudicially that the involvement Children in the judicial process basically will give birth to stigmatization and will affect the mental condition of the child.

2. The application of criminal sanctions for narcotics offenders committed by children is based on specific considerations, namely: a) Juridical Considerations, b) Sociological Considerations, c) Psychological considerations, d) Philosophical Considerations. During the examination process at court regarding cases of criminal narcotics committed by children at the trial, witnesses and defendants have been present to convey their statements clearly so that there are no things that hinder the proceedings of the criminal case examination at trial. Criminal threats for children can only be imposed $1 / 2$ (one half) of the greatest threat from adults based on the provisions of Law No.11 of 2012 concerning the Juvenile Criminal Justice System, against children who are perpetrators of narcotics crime with the existence of Diversion if The case of children can be resolved non-judicially, that the involvement of children in the judicial process will result in stigmatization and affect the mental condition of the child.

\section{B. Suggestions}

The suggestions in this study are:

1. Law enforcement officers should be provided with knowledge of child psychology in conducting examination of a child suspect / defendant and are obliged to pay attention to the mental condition and rights of the child and the judge before making a verdict on the child perpetrator of narcotics crime, must pay attention to juridical considerations and considerations. non-juridical considerations, in order to achieve justice and benefit in the punishment of children who are offenders of narcotics crimes.

2. In the criminal provisions against Narcotics Abuse according to Law no. 35 of 2009, should not 
only provide criminal threats in the form of imprisonment, but should also regulate alternative criminal threats such as imprisonment or fines, because imprisonment in the Narcotics Law which is generally applied to people who commit narcotics offenses if the perpetrator is a child cannot guarantee the best interests of the child. So that sanctions can determine and impose appropriate sanctions for children, so that they are in accordance with the purpose of punishment that is beneficial to the child's future, and not the other way around.

\section{REFERENCES}

[1] Book

[2] Bandar Nawawi Arief, "Legal Policy Issues and Crime Enforcement", (Bandung: PT Citra Aditya Bakti, 2001), p. 56

[3] Beniharmoni Harefa, Vivi Ariyanti, Regarding the Development of the Juvenile Criminal Justice System and Narcotics in Indonesia, Deepublish, Yogyakarta, 2016, pp. 85

[4] Chainur Arrasjid, Basics of legal science, (Jakarta, PT Sinar Grafika, 2000), p. 134

[5] Gatot Supramono, Procedure for the Juvenile Court, (Jakarta: Djambat, 2007), p. 1

[6] Marlina, Juvenile Criminal Court in Indonesia, (Bandung: Refika Aditama, 2012), p. XV

[7] M. Nasir Djamil, "Children are not to be punished", (East Jakarta: Sinar Grafika), p. 127

[8] Nandang Sambas, "Reforming the Juvenile Criminal Justice System Based on Law no. 11 of 2012 concerning the Criminal Justice System for Children ", (Volume 4 Number 1, 2014), p. 63

[9] R. Achmad Soema Di Pradja, "Principles of Criminal Law" (Bandung: Alumni, 1982), p. 265

[10] Ridho Mubarak and Wessy Trisna, "Child Crime Law" (Medan: Medan Area University Press, 2012), p. 72

[11] Talib Setiady, Principles of Indonesian Penitentiary Law, (Bandung, Alfabeta. 2010). p. 173

[12] Wagiati Soetodjo, Child Criminal Law, (Bandung: Refika Aditama, 2006), p. 33-34

[13] Legislation

[14] Part considering letter $b$ and letter $c$ in Law no. 23 of 2002 concerning Child Protection

[15] Article 64 of RI Law No. 22 of 1997 on Narcotics, (Bandung, Citra Umbara, 2003), p. 175

[16] Article of Law no. 11 of 2012 on Juvenile Court
[18] Christoforus Ristianto, BNN Call the Abuse and Circulation of Narcotics Increasing, accessed from HTTP: //in.go.id/penggunanarkotika-kalangan-remaja-men Increase/, On April 6, 2021 at 17.40 WIB

[19] KPAI, 2019 Data on Child Complaint Cases Based on the Child Protection Cluster, (Jakarta: KPAI)

[20] Paragraphs 32-38 General Comment No 10, downloaded from http://www2.ohchr.org/english/ bodies / crc / docs / CRC.C.GC.10.pdf dated 15 July 2017

[21] Elucidation of Law No. 11 of 2012 concerning the Criminal Justice System for Children, http://peraturan.go.id/uu/nomor-11-tahun2012.html22 downloaded on April 4, 2021

[22] Tri Jata Ayu Pramesti, "Important Matters Regulated in the Law on the Criminal Justice System for Children" (https://m.hukumonline.com/klinik/detail/ulasa n/lt53f55d0f46878/halhalpentingyangdiaturdal amuusistemperadilanpidanaanak/\#. :text=Dive rsi\%20adalah\% 20 transfer\% 20 completion\% 20 case, process $\% 20$ in $\% 20$ outside $\% 20$ court $\% 20$ criminal. \& Text $=$ consequences $\%$ $20 \mathrm{C} \% 20$ children $\% 20$ victims $\% 20$ and $\% 20$ children $\% 20$ witness $\% 20$ no $\% 20$ get $\% 20$ protection\% 20 law) Accessed on December 15,2020 at $16.19 \mathrm{WIB}$

[17] Internet 